\title{
Komparasi Metode Logika Fuzzy Mamdani dan Metode Logika Fuzzy Sugeno Sebagai Pendukung Keputusan Seleksi Bertahap
}

Oleh

\author{
: Dedy Mulyadi
}

\begin{abstract}
Abstrak
Seleksi bertahap pada penerimaan mahasiswa baru program studi Diploma III Akuntansi STIE Binaniaga Bogor melalui jalur beasiswa selama ini menggunakan metode rata-rata. Harapan minimal yang diinginkan STIE Binaniaga adalah semakin tinggi nilai hasil seleksi bertahap maka akan semakin tinggi pula prestasi akademik dalam perjalanan studi mahasiswa. Penggunaan metode rata-rata belum menunjukan hasil sebagaimana harapan minimal yang diinginkan, ditunjukkan dengan pola visualisasi prestasi akademik yang masih terdapat beberapa fluktuasi menaik dan menurun. Tujuan dari penelitian adalah membandingkan metode logika fuzzy Mamdani dengan metode logika fuzzy Sugeno untuk dapat ditentukan metode logika fuzzy mana yang lebih baik diterapkan pada setiap tahapan seleksi. Alat analisa yang digunakan adalah perbandingan (komparasi) berdasarkan hubungan (korelasi) antara prestasi akademik dengan masing-masing penerapan kombinasi metode logika fuzzy pada seluruh tahapan seleksi. Korelasi antara indeks prestasi kumulatif dengan hasil akhir dari penerapan metode rata-rata adalah sebesar 0,559. Penerapan kombinasi metode logika fuzzy yang dapat menghasilkan korelasi dengan indeks prestasi kumulatif melebihi 0,559 merupakan alternatif penerapan metode yang lebih baik untuk menggantikan metode rata-rata yang selama ini digunakan. Hal tersebut tercapai pada kombinasi penerapan logika fuzzy: SMMM (0,570), SMSM (0,570), SSMM (0,571), SSSM $(0,570)$, SMSS $(0,579)$, dan SSSS (0,569). Mengingat nilai koefisien korelasi linier antara indeks prestasi kumulatif dengan hasil seleksi bertahap dari penerapan kombinasi metode logika fuzzy tertinggi dan lebih besar dari 0,559 dicapai pada penerapan kombinasi metode logika fuzzy SMSS yaitu sebesar 0,579 maka kombinasi logika fuzzy SMSS (Sugeno, Mamdani, Sugeno, Sugeno) lebih baik untuk diterapkan pada setiap tahapan seleksi yang bersesuaian. Sehingga, kesimpulan penelitian yang didapatkan adalah: metode logika fuzzy Sugeno lebih baik untuk diterapkan sebagai pendukung keputusan pada seleksi tahap pertama, metode logika fuzzy Mamdani lebih baik untuk diterapkan sebagai pendukung keputusan pada seleksi tahap kedua, metode logika fuzzy Sugeno lebih baik untuk diterapkan sebagai pendukung keputusan pada seleksi tahap ketiga, dan metode logika fuzzy Sugeno lebih baik untuk diterapkan sebagai pendukung keputusan pada seleksi tahap akhir.
\end{abstract}

Kata Kunci : Komparasi, Logika Fuzzy, Sugeno, Mamdani

\section{Pendahuluan}

Salah satu kegiatan rutin tahunan yang dihadapi oleh para pengelola perguruan tinggi swasta (PTS) di Indonesia adalah penerimaan mahasiswa baru (PMB). Berbagai macam gaya dan pola perekrutan mahasiswa baru diterapkan oleh masing-masing perguruan tinggi swasta seakan kegiatan penerimaan mahasiswa baru adalah kompetisi untuk memperebutkan para calon mahasiswa sehingga tertarik dan bergabung melanjutkan studi di perguruan tinggi swasta yang dikelola.

Salah satu bagian kegiatan dalam proses penerimaan mahasiswa baru adalah seleksi terhadap calon mahasiswa baru, meskipun masih ada beberapa perguruan tinggi swasta yang melewatkan bagian kegiatan tersebut. Beberapa perguruan tinggi swasta yang belum atau tidak menyelenggarakan seleksi terhadap calon mahasiswa baru menganggap belum saatnya melakukan seleksi akan tetapi lebih mengedepankan kuantitas perolehan mahasiswa baru untuk mendukung berjalannya penyelenggaraan pendidikan di perguruan tinggi swasta yang dikelola. Bagi perguruan tinggi swasta yang menyelenggarakan kegiatan seleksi terhadap calon mahasiswa baru, terdapat beberapa kemungkinan yang menjadi pertimbangan diantaranya:

1. Mendapatkan mahasiswa baru yang berkualitas sesuai dengan yang diharapkan. 
2. Selain kualitas mahasiswa baru, juga membatasi kuantitasnya mengingat keterbatasan daya tampung yang dimiliki.

3. Membatasi kuantitas mahasiswa baru untuk menjaga kesesuaian rasio mahasiswa dan Dosen Tetap sesuai regulasi pemerintah yang saat ini diberlakukan, kecuali bagi perguruan tinggi swasta yang tidak ada masalah dengan perekrutan dan penyediaan Dosen Tetap.

4. Memenuhi penilaian akreditasi baik program studi maupun institusi pada perguruan tinggi swasta yang dikelola.

Bentuk dan gaya seleksi terhadap calon mahasiswa baru juga dapat berbeda antara perguruan tinggi swasta yang satu dengan lainnya. Mulai dari kegiatan seleksi yang paling sederhana yaitu hanya wawancara (interview), kemudian dapat ditambah dengan kombinasi kegiatan seleksi diantara: tes tertulis, psychotest, tes kesehatan, tes fisik, dan lainnya.

Metode perhitungan saat ini yang dilakukan STIE Binaniaga adalah menggunakan metode rata-rata. Hasil seleksi tahap pertama berupa tes tertulis adalah rata-rata dari 3 (tiga) nilai materi tes (matematika, bahasa Inggris, dan pengetahuan umum). Hasil seleksi tahap kedua berupa psychotest adalah rata-rata dari 6 (enam) nilai aspek psychotest (intelegensi, daya tangkap, daya analisa, motivasi berprestasi, daya tahan terhadap stres, dan kerja sama). Hasil seleksi tahap ketiga berupa wawancara adalah nilai wawancara itu sendiri, sama artinya dengan rata-rata dari 1 (satu) materi tes yaitu wawancara. Hasil akhir seleksi bertahap adalah rata-rata dari 3 (tiga) hasil penilaian setiap tahapan seleksi.

Pada seleksi tahap pertama yaitu tes tertulis hasil penilaiannya secara logika dapat dikategorikan sebagai kategori "rendah", "sedang", atau "tinggi" namun tetap dengan besaran nilai sesuai dari hasil perhitungan. Begitu pula dengan hasil penilaian tahap kedua, hasil penilaian tahap ketiga, dan hasil penilaian keseluruhan. Matode yang dapat mengakomodasi pengkategorian tersebut adalah metode logika fuzzy, dan penulis memandang bahwa metode logika fuzzy dapat menjadi alternatif untuk diterapkan dalam metode perhitungan hasil seleksi bertahap baik pada setiap tahapan seleksi maupun perhitungan hasil akhir keseluruhan dari seluruh tahapan seleksi.

Metode logika fuzzy yang umum dan telah banyak digunakan dalam berbagai bidang adalah metode logika fuzzy Mamdani, metode logika fuzzy Sugeno, dan metode logika fuzzy Tsukamoto. Permasalahan berikutnya adalah metode logika fuzzy mana yang menjadi alternatif untuk diterapkan pada proses seleksi bertahap penerimaan mahasiswa baru program studi Diploma III Akuntansi melalui jalur beasiswa sehingga harapan minimal yang diinginkan STIE Binaniaga dapat terpenuhi.

\section{Rumusan Masalah}

Berdasarkan uraian identifikasi masalah dan ruang lingkup masalah di atas, dan untuk mendapatkan alternatif lain yang lebih baik dari penggunaan metode rata-rata, maka rumusan masalah yang harus terjawab dalam penelitian ini adalah: 
1. Apakah metode logika fuzzy Mamdani atau metode logika fuzzy Sugeno yang lebih baik diterapkan dalam perhitungan hasil seleksi tahap pertama yaitu tes tertulis pada penerimaan mahasiswa baru program studi Diploma III Akuntansi STIE Binaniaga melalui jalur beasiswa?

2. Apakah metode logika fuzzy Mamdani atau metode logika fuzzy Sugeno yang lebih baik diterapkan dalam perhitungan hasil seleksi tahap kedua yaitu psychotest pada penerimaan mahasiswa baru program studi Diploma III Akuntansi STIE Binaniaga melalui jalur beasiswa?

3. Apakah metode logika fuzzy Mamdani atau metode logika fuzzy Sugeno yang lebih baik diterapkan dalam perhitungan hasil seleksi tahap ketiga yaitu wawancara pada penerimaan mahasiswa baru program studi Diploma III Akuntansi STIE Binaniaga melalui jalur beasiswa?

4. Apakah metode logika fuzzy Mamdani atau metode logika fuzzy Sugeno yang lebih baik diterapkan dalam perhitungan hasil akhir keseluruhan tahapan seleksi pada penerimaan mahasiswa baru program studi Diploma III Akuntansi STIE Binaniaga melalui jalur beasiswa?

\section{Tujuan Penelitian}

Tujuan dari penelitian komparasi penerapan metode logika fuzzy Mamdani dan metode logika fuzzy Sugeno sebagai pendukung keputusan seleksi bertahap pada penerimaan mahasiswa baru jalur beasiswa adalah:

1. Terpilih satu metode logika fuzzy yang lebih baik diterapkan dalam perhitungan hasil seleksi tahap pertama yaitu tes tertulis pada penerimaan mahasiswa baru program studi Diploma III Akuntansi sehingga dapat memenuhi harapan minimal yang diinginkan STIE Binaniaga

2. Terpilih satu metode logika fuzzy yang lebih baik diterapkan dalam perhitungan hasil seleksi tahap kedua yaitu psychotest pada penerimaan mahasiswa baru program studi Diploma III Akuntansi sehingga dapat memenuhi harapan minimal yang diinginkan STIE Binaniaga.

3. Terpilih satu metode logika fuzzy yang lebih baik diterapkan dalam perhitungan hasil seleksi tahap ketiga yaitu wawancara pada penerimaan mahasiswa baru program studi Diploma III Akuntansi sehingga dapat memenuhi harapan minimal yang diinginkan STIE Binaniaga.

4. Terpilih satu metode logika fuzzy yang lebih baik diterapkan dalam perhitungan hasil akhir keseluruhan tahapan seleksi pada penerimaan mahasiswa baru program studi Diploma III Akuntansi sehingga dapat memenuhi harapan minimal yang diinginkan STIE Binaniaga. 


\section{Landasan Teori}

\section{Metode Logika Fuzzy}

Konsep tentang logika fuzzy diperkenalkan oleh Prof. Lotfi Astor Zadeh pada 1965 (Kusumadewi, 2010). Logika fuzzy adalah metodologi sistem kontrol pemecahan masalah, yang cocok untuk diimplementasikan pada sistem, mulai dari sistem yang sederhana, sistem kecil, embedded system, jaringan PC, multichannel atau workstation berbasis akuisisi data, dan sistem kontrol. Metodologi ini dapat diterapkan pada perangkat keras, perangkat lunak, atau kombinasi keduanya.

Dalam logika klasik dinyatakan bahwa segala sesuatu bersifat biner, yang artinya hanya mempunyai dua kemungkinan, "Ya atau Tidak", "Benar atau Salah", "Baik atau Buruk", dan lainlain. Oleh karena itu, semua ini dapat mempunyai nilai keanggotaan 0 atau 1. Akan tetapi, dalam logika fuzzy kemungkinan nilai keanggotaan berada diantara 0 dan 1. Artinya, bisa saja suatu keadaan mempunyai dua nilai "Ya dan Tidak", "Benar dan Salah", "Baik dan Buruk" secara bersamaan, namun besar nilainya tergantung pada bobot keanggotaan yang dimilikinya.

\section{Metode Logika Fuzzy Mamdani}

Metode logika fuzzy Mamdani dikenal juga sebagai metode min-max, diperkenalkan oleh Ebrahim Mamdani pada tahun 1975. Menurut Much. Djunaidi, Eko Setiawan, dan Fajar Whedi Andista (2005), untuk mendapatkan output diperlukan 4 tahapan, yaitu:

1. Pembentukan Himpunan Fuzzy

2. Aplikasi Fungsi Implikasi

3. Komposisi Aturan

4. Penegasan (Defuzzification)

\section{Metode Logika Fuzzy Sugeno}

Penalaran dengan metode Sugeno hampir sama dengan penalaran Mamdani, hanya saja output (konsekuen) sistem tidak berupa himpunan fuzzy, melainkan berupa konstanta atau persamaan linear. Metode ini diperkenalkan oleh Takagi-Sugeno Kang pada tahun 1985 (Kusumadewi dan Purnomo, 2010).

1. Pembentukan Himpunan Fuzzy

2. Aplikasi Fungsi Implikasi

3. Komposisi Aturan

4. Penegasan (Defuzzification)

5. Penerapan metode logika fuzzy Sugeno banyak digunakan untuk menangani masalahmasalah controll.

6. Output (konsekuen) sistem pada metode logika fuzzy Sugeno tidak berupa himpunan fuzzy, melainkan berupa konstanta (orde-nol) atau persamaan linear (orde-satu). 


\section{Koefisien Korelasi Linear}

Koefisien korelasi linear $(r)$, berfungsi untuk mengetahui hubungan perilaku data dalam suatu gugus data (variabel) dengan perilaku data pada gugus data (variabel) lainnya (misal, $\mathrm{X}$ dan Y).

Nilai koefisien korelasi linear antara variabel $X$ dengan variabel $Y$ dihitung menggunakan rumus (Walpole, 1988):

$$
r=\frac{n \sum_{i=1}^{n} x_{i} y_{i}-\left(\sum_{i=1}^{n} x_{i}\right)\left(\sum_{i=1}^{n} y_{i}\right)}{\sqrt{\left[n \sum_{i=1}^{n} x_{i}^{2}-\left(\sum_{i=1}^{n} x_{i}\right)^{2}\left[n \sum_{i=1}^{n} y_{i}^{2}-\left(\sum_{i=1}^{n} y_{i}\right)^{2}\right]\right.}}
$$

Nilai koefisien korelasi yang mungkin terjadi ada dalam batasan $-1 \leq r \leq 1$. Apabila batasan nilai tersebut disajikan dalam bentuk garis bilangan maka akan terlihat sebagaimana dalam Gambar 1.

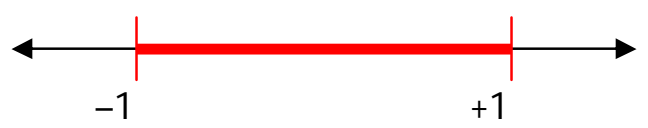

\section{Gambar 1 Batasan Nilai Koefisien Korelasi Linear ( $r)$}

Dari besaran nilai koefisien korelasi $(r)$ di atas, dapat dibagi ke dalam 3 bagian yaitu:

1. Korelasi Positif dengan $0<\mathrm{r} \leq+1$.

2. Tidak Berkorelasi dengan $\mathrm{r}=0$.

3. Korelasi Negatif dengan $-1 \leq r<0$.

Arti dari masing-masing bagian nilai koefisien korelasi linear $(r)$ adalah:

1. Korelasi Positif.

Semakin tinggi nilai $X$ maka semakin tinggi pula nilai $Y$. Atau sebaliknya, semakin rendah nilai $X$ akan semakin rendah pula nilai $Y$.

2. Tidak Berkorelasi.

Perubahan yang terjadi pada nilai $X$ tidak akan mempengaruhi pada nilai $Y$. Atau sebaliknya, perubahan yang terjadi pada nilai $Y$ tidak akan mempengaruhi nilai $X$.

3. Korelasi Negatif.

Semakin tinggi nilai $X$ maka akan semakin rendah nilai $Y$. Atau sebaliknya, semakin rendah nilai $X$ akan semakin tinggi nilai $Y$.

\section{Metode Penelitian}

\section{Jenis Penelitian}

Penelitian yang dilakukan penulis ini termasuk ke dalam jenis penelitian deskriptif komparatif. Hasil pengumpulan data dideskripsikan dengan cara membandingkan (komparasi) penerapan 2 (dua) metode logika fuzzy yaitu metode logika fuzzy Mamdani dan metode logika 
fuzzy Sugeno untuk kemudian dapat ditentukan metode logika fuzzy apa yang lebih baik diterapkan pada setiap tahapan seleksi penerimaan mahasiswa baru program studi Diploma III Akuntansi STIE Binaniaga melalui jalur beasiswa, sebagai alternatif untuk menggantikan metode rata-rata yang selama ini digunakan.

\section{Metode Analisa Data}

\section{Teknik Pengolahan Data}

Terlebih dahulu metode logika fuzzy Mamdani dan metode logika fuzzy Sugeno diterapkan pada proses perhitungan hasil pada seleksi tahap pertama (tes tertulis), seleksi tahap kedua (psychotest), dan seleksi tahap ketiga (wawancara). Pada seleksi tahap akhir, akan diterapkan pula metode logika fuzzy Mamdani dan metode logika fuzzy Sugeno menggunakan input berupa kombinasi hasil penerapan metode logika fuzzy pada seleksi tahap pertama, seleksi tahap kedua, dan seleksi tahap ketiga. Sehingga secara keseluruhan akan terbentuk 16 (enam belas) kombinasi penerapan metode logika fuzzy pada seleksi tahap pertama, seleksi tahap kedua, seleksi tahap ketiga, dan seleksi tahap akhir. Kombinasi penerapan metode logika fuzzy yang dimaksudkan adalah (bersesuaian dengan tahapan seleksi): Mamdani-MamdaniMamdani-Mamdani (MMMM), MMSM, MSMM, MSSM, SMMM, SMSM, SSMM, SSSM, MMMS, MMSS, MSMS, MSSS, SMMS, SMSS, SSMS, dan SSSS.

Setelah hasil penerapan kombinasi metode logika fuzzy pada setiap tahapan seleksi didapatkan, maka analisis deskriptif selanjutnya yang dilakukan adalah perbandingan (komparasi).

Pembandingan (komparasi) hasil penerapan kombinasi metode logika fuzzy dilakukan melalui:

1. Tingkat kedekatan pola visualisasi IPK berdasarkan hasil seleksi terurut dengan pola visualisasi IPK yang diharapkan STIE Binaniaga

2. Hubungan (korelasi) antara prestasi akademik berupa indeks prestasi kumulatif (IPK) dengan masing-masing hasil setiap tahapan seleksi penerimaan mahasiswa baru program studi Diploma III Akuntansi STIE Binaniaga melalui jalur beasiswa.

Penentuan kombinasi metode logika fuzzy apa yang lebih baik diterapkan pada setiap tahapan seleksi penerimaan mahasiswa baru program studi Diploma III Akuntansi STIE Binaniaga melalui jalur beasiswa lebih diutamakan dari korelasi antara prestasi akademik berupa indeks prestasi kumulatif (IPK) dengan masing-masing hasil setiap tahapan seleksi yang paling mendekati 1 atau persis sama dengan 1 (sempurna).

Kombinasi penerapan metode logika fuzzy yang memiliki korelasi tertinggi mendekati 1 atau persis sama dengan 1 (sempurna) dengan prestasi akademik berupa indeks prestasi kumulatif (IPK) maka kombinasi penerapan metode logika fuzzy tersebut yang terpilih dan lebih baik diterapkan pada setiap tahapan seleksi bersesuaian, sebagai alternatif menggantikan metode rata-rata yang selama ini digunakan. 


\section{Hasil dan Pembahasan \\ Hasil Pengumpulan Data}

Data sekunder yang digunakan dalam penelitian ini adalah nilai hasil seleksi bertahap penerimaan mahasiswa baru program studi Diploma III Akuntansi STIE Binaniaga melalui jalur beasiswa, dan data prestasi akademik mahasiswa yang diterima melalui jalur beasiswa tersebut. Mengingat seleksi bertahap yang terdiri dari 4 (empat) tahapan, dan 3 (tiga) tahapan seleksi diantaranya yaitu seleksi tahap pertama (tes tertulis), seleksi tahap kedua (psychotest), dan seleksi tahap ketiga (wawancara) baru lengkap diterapkan pada tahun akademik 20142015 maka yang digunakan adalah data hasil seleksi dan perkembangan prestasi akademik dari 23 (dua puluh tiga) mahasiswa yang diterima pada program studi Diploma III Akuntansi melalui jalur beasiswa pada tahun akademik tersebut.

Data hasil seleksi tahap pertama terdiri dari nilai tes tertulis yang terdiri dari 3 (tiga) materi tes terulis yaitu Matematika (materi 1), Bahasa Inggris (materi 2), dan Pengetahuan Umum (materi 3). Kolom "Hasil" adalah rata-rata dari 3 (tiga) nilai materi tes tertulis.

Penentuan besaran beasiswa bagi mahasiswa yang diterima pada program studi Diploma III Akuntansi STIE Binaniaga pada tahun akademik 2014-2015 ditentukan berdasarkan nilai akhir seleksi bertahap yang telah dilalui. Beasiswa sebesar $100 \%$ bebas biaya pendidikan diberikan bagi mahasiswa yang memiliki nilai akhir seleksi bertahap di atas 70 (nilai akhir > 70). Sedangkan beasiswa sebesar $50 \%$ bebas biaya pendidikan diberikan bagi mahasiswa yang memiliki nilai akhir seleksi bertahap maksimal 70 (nilai akhir $\leq 70$ ).

Data prestasi akademik adalah berupa indeks prestasi (IP) atau indeks prestasi kumulatif (IPK) hasil studi yang diperoleh mahasiswa dari semester yang telah dijalaninya. Saat penelitian ini dilakukan, mahasiswa yang dimaksudkan sedang duduk di semester II, sehingga indeks prestasi kumulatif (IPK) adalah juga merupakan indeks prestasi (IP) masing-masing mahasiswa setelah menyelesaikan studi di semester I.

Data berupa besaran beasiswa dan prestasi akademik masing-masing mahasiswa yang diterima melalui jalur beasiswa pada program studi Diploma III Akuntansi STIE Binaniaga sebagai hasil seleksi bertahap pada tahun akademik 2014-2015 sebagaimana tercantum dalam Tabel 1.

Tabel 1. Data Nilai Akhir, Besaran Beasiswa, dan Prestasi Akademik

\begin{tabular}{|c|l|c|c|l|}
\hline NO. & NAMA & $\begin{array}{l}\text { NILAI } \\
\text { AKHIR } \\
\text { (RATA-RATA }\end{array}$ & BEASISWA & $\begin{array}{l}\text { INDEKS } \\
\text { PRESTASI } \\
\text { KUMULATIF }\end{array}$ \\
\hline \hline & & & & \\
\hline 1 & Mahasiswa 01 & 90 & $100 \%$ & 4,00 \\
\hline 2 & Mahasiswa 02 & 78 & $100 \%$ & 3,55 \\
\hline 3 & Mahasiswa 03 & 76 & $100 \%$ & 3,25 \\
\hline 4 & Mahasiswa 04 & 74 & $100 \%$ & 3,55 \\
\hline 5 & Mahasiswa 05 & 72 & $100 \%$ & 3,55 \\
\hline 6 & Mahasiswa 06 & 72 & $100 \%$ & 3,55 \\
\hline
\end{tabular}




\begin{tabular}{|c|l|l|l|l|}
\hline NO. & NAMA & $\begin{array}{l}\text { NILAI } \\
\text { AKHIR } \\
\text { (RATA-RATA }\end{array}$ & BEASISWA & $\begin{array}{l}\text { INDEKS } \\
\text { PRESTASI } \\
\text { KUMULATIF }\end{array}$ \\
\hline \hline & & & & \\
\hline 7 & Mahasiswa 07 & 73 & $100 \%$ & 3,15 \\
\hline 8 & Mahasiswa 08 & 75 & $100 \%$ & 3,25 \\
\hline 9 & Mahasiswa 09 & 73 & $100 \%$ & 3,55 \\
\hline 10 & Mahasiswa 10 & 74 & $100 \%$ & 3,45 \\
\hline 11 & Mahasiswa 11 & 73 & $100 \%$ & 3,45 \\
\hline 12 & Mahasiswa 12 & 90 & $100 \%$ & 3,55 \\
\hline 13 & Mahasiswa 13 & 85 & $100 \%$ & 3,85 \\
\hline 14 & Mahasiswa 14 & 80 & $100 \%$ & 3,00 \\
\hline 15 & Mahasiswa 14 & 79 & $100 \%$ & 4,00 \\
\hline 16 & Mahasiswa 16 & 77 & $100 \%$ & 3,25 \\
\hline 17 & Mahasiswa 17 & 72 & $100 \%$ & 3,25 \\
\hline 18 & Mahasiswa 18 & 71 & $100 \%$ & 3,55 \\
\hline 19 & Mahasiswa 19 & 73 & $100 \%$ & 3,10 \\
\hline 20 & Mahasiswa 20 & 72 & $100 \%$ & 3,15 \\
\hline 21 & Mahasiswa 21 & 69 & $50 \%$ & 2,30 \\
\hline 22 & Mahasiswa 22 & 65 & $50 \%$ & $50 \%$ \\
\hline 23 & Mahasiswa 23 & 66 & & \\
\hline & & & & \\
\hline & & & & \\
\hline
\end{tabular}

Data yang sudah diperoleh penulis di atas, kemudian menjadi bahan untuk dilakukan pengolahan data berupa penerapan metode logika fuzzy Mamdani dan metode logika fuzzy Sugeno pada setiap tahapan seleksi penerimaan mahasiswa baru program studi Diploma III Akuntansi STIE Binaniaga melalui jalur beasiswa, ataupun penerapan prosedur lainnya yang diperlukan dalam penelitian ini.

\section{Penerapan Metode Logika Fuzzy Mamdani}

Dalam penerapan metode logika fuzzy Mamdani pada seleksi tahap pertama, penulis menggunakan alat bantu berupa program aplikasi MATLAB 2013a.

Diawali dengan pendefinisian variabel input dan variabel output yang digunakan pada seleksi tahap pertama ini. Variabel input terdiri dari Matematika, Bahasa Inggris, dan Pengetahuan Umum. Sedangkan variabel outputnya adalah Hasil Seleksi Tahap Pertama. Penulisan nama variabel dalam program aplikasi disesuaikan dengan tatacara yang diberlakukan MATLAB 2013a.

Dilanjutkan dengan pembentukan himpunan semesta dan himpunan fuzzy dari setiap variabel, baik variabel input maupun variabel output. Himpunan semesta dan himpunan fuzzy yang digunakan adalah sebagaimana yang telah tercantum dalam Tabel 1 yang apabila disajikan kembali adalah sebagai berikut: 
Tabel 1 Himpunan Semesta dan Himpunan Fuzzy

\begin{tabular}{|c|c|c|c|c|}
\hline Variabel & Nama Variabel & $\begin{array}{l}\text { Himpunan } \\
\text { Semesta }\end{array}$ & $\begin{array}{l}\text { Himpunan } \\
\text { Fuzzy }\end{array}$ & Domain \\
\hline \multirow{9}{*}{ Input } & \multirow{3}{*}{ Matematika } & \multirow{3}{*}{$000-100$} & Rendah & $000-055$ \\
\hline & & & Sedang & $045-075$ \\
\hline & & & Tinggi & $065-100$ \\
\hline & \multirow{3}{*}{ Bahasa Inggris } & \multirow{3}{*}{$000-100$} & Rendah & $000-055$ \\
\hline & & & Sedang & $045-075$ \\
\hline & & & Tinggi & $065-100$ \\
\hline & \multirow{3}{*}{$\begin{array}{l}\text { Pengetahuan } \\
\text { Umum }\end{array}$} & \multirow{3}{*}{$000-100$} & Rendah & $000-055$ \\
\hline & & & Sedang & $045-075$ \\
\hline & & & Tinggi & $065-100$ \\
\hline \multirow{3}{*}{ Output } & \multirow{3}{*}{$\begin{array}{l}\text { Hasil Seleksi Tahap } \\
\text { Pertama }\end{array}$} & \multirow{3}{*}{$000-100$} & Rendah & $000-055$ \\
\hline & & & Sedang & $045-075$ \\
\hline & & & Tinggi & $065-100$ \\
\hline
\end{tabular}

Guna mendapatkan hasil (output) yang sesuai dengan keinginan, terlebih dahulu didefinisikan komposisi aturan-aturan (rules) yang diberlakukan dalam penerapan metode logika fuzzy Mamdani. Hal tersebut dilakukan pada fasilitas Rule Editor sebagaimana dalam tampilan Gambar 1.

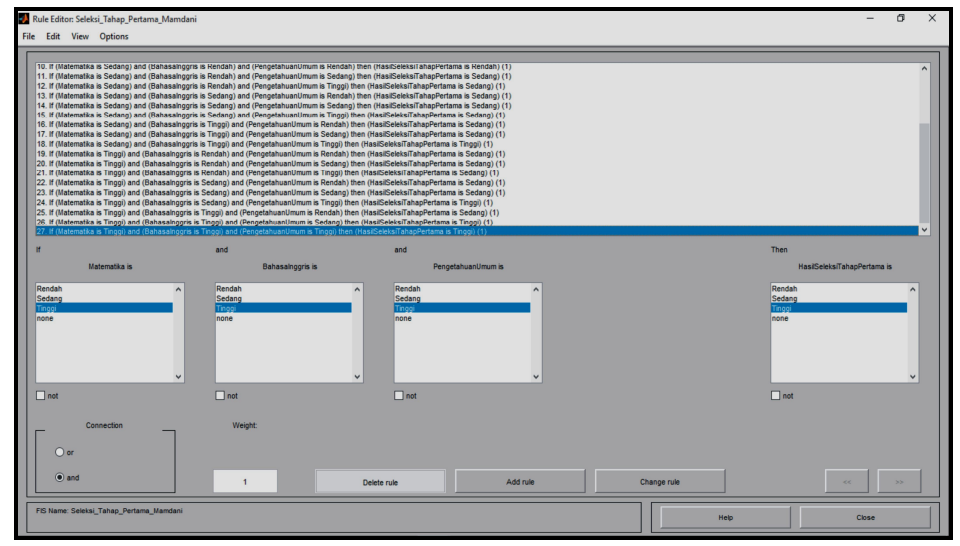

Gambar 1 Rule Editor untuk Penentuan Aturan (Rule) Metode Mamdani pada Seleksi Tahap Pertama

Jumlah komposisi aturan sebanyak 27 (dua puluh tujuh) diperoleh dari kombinasi yang mungkin dari 3 (tiga) variabel input yang ada, masing-masing variabel input memiliki 3 (tiga) himpunan fuzzy yaitu "Rendah", "Sedang", dan "Tinggi". Sehingga akan terbentuk kombinasi aturan sebanyak $3 \times 3 \times 3=27$ aturan. 
Tabel 2 Data Hasil Tes Tahap Akhir Menggunakan Metode Logika Fuzzy Mamdani Berdasarkan Kombinasi Hasil Tiga Tahapan Seleksi : Mamdani, Mamdani, Mamdani

\begin{tabular}{|c|c|c|c|c|c|c|}
\hline \multirow{3}{*}{ NO } & \multirow{3}{*}{ NAMA } & \multicolumn{3}{|c|}{ KOMBINASI HASIL TAHAPAN SELEKSI } & \multirow{3}{*}{$\begin{array}{l}\text { HASIL AKHIR } \\
\text { (MAMDANI) }\end{array}$} & \multirow{3}{*}{ IPK } \\
\hline & & PERTAMA & KEDUA & KETIGA & & \\
\hline & & MAMDANI & MAMDANI & MAMDANI & & \\
\hline 1 & Mahasiswa 01 & 86,7 & 85,1 & 86,7 & 86.7 & 4,00 \\
\hline 2 & Mahasiswa 02 & 51,5 & 86,2 & 86,7 & 46,3 & 3,55 \\
\hline 3 & Mahasiswa 03 & 60,0 & 85,1 & 86,7 & 60,0 & 3,25 \\
\hline 4 & Mahasiswa 04 & 55,6 & 85,1 & 86,7 & 60,0 & 3,55 \\
\hline 5 & Mahasiswa 05 & 60,0 & 85,1 & 86,2 & 60,0 & 3,55 \\
\hline 6 & Mahasiswa 06 & 60,0 & 85,1 & 86,2 & 60,0 & 3,55 \\
\hline 7 & Mahasiswa 07 & 31,3 & 85,1 & 86,7 & 21,9 & 3,15 \\
\hline 8 & Mahasiswa 08 & 32,1 & 85,1 & 86,7 & 22,0 & 3,25 \\
\hline 9 & Mahasiswa 09 & 48,0 & 85,1 & 86,7 & 34,6 & 3,55 \\
\hline 10 & Mahasiswa 10 & 24,6 & 85,1 & 86,7 & 21,1 & 3,45 \\
\hline 11 & Mahasiswa 11 & 51,7 & 85,1 & 86,7 & 47,0 & 3,45 \\
\hline 12 & Mahasiswa 12 & 86,7 & 86,2 & 86,7 & 86,7 & 3,55 \\
\hline 13 & Mahasiswa 13 & 86,7 & 86,2 & 86,2 & 86,7 & 3,85 \\
\hline 14 & Mahasiswa 14 & 82,6 & 85,1 & 86,2 & 86,7 & 3,00 \\
\hline 15 & Mahasiswa 15 & 60,0 & 85,1 & 86,7 & 60,0 & 3,85 \\
\hline 16 & Mahasiswa 16 & 60,0 & 85,1 & 86,2 & 60,0 & 4,00 \\
\hline 17 & Mahasiswa 17 & 31,3 & 85,1 & 86,2 & 21,9 & 3,25 \\
\hline 18 & Mahasiswa 18 & 44,6 & 85,1 & 86,2 & 24,7 & 3,25 \\
\hline 19 & Mahasiswa 19 & 24,6 & 85,1 & 86,7 & 21,1 & 3,55 \\
\hline 20 & Mahasiswa 20 & 24,6 & 85,1 & 86,7 & 21,1 & 3,10 \\
\hline 21 & Mahasiswa 21 & 22,8 & 85,1 & 86,2 & 21,1 & 3,15 \\
\hline 22 & Mahasiswa 22 & 25,0 & 85,1 & 86,2 & 21,1 & 2,30 \\
\hline 23 & Mahasiswa 23 & 24,8 & 85,1 & 86,7 & 21,1 & 3,55 \\
\hline
\end{tabular}

Hasil yang diperoleh dari penerapan metode logika fuzzy Mamdani pada seleksi tahap pertama, tahap kedua, tahap ketiga, dan tahap akhir di atas djadikan sebagai bahan analisa perbandingan (komparasi) dengan hasil penerapan logika fuzzy Sugeno sebagaimana dalam uraian berikutnya.

\section{Penerapan Metode Logika Fuzzy Sugeno}

Dalam penerapan metode logika fuzzy Sugeno pada seleksi tahap pertama, diawali pula dengan pendefinisian variabel input dan variabel output yang digunakan pada seleksi tahap pertama ini. Variabel input terdiri dari Matematika, Bahasa Inggris, dan Pengetahuan Umum. Sedangkan variabel outputnya adalah Hasil Seleksi Tahap Pertama. Penulisan nama variabel dalam program aplikasi disesuaikan dengan tatacara yang diberlakukan MATLAB 2013a.

Pendefinisian variabel input dan variabel output yang penulis lakukan, sebagaimana tercantum dalam Gambar 2. 


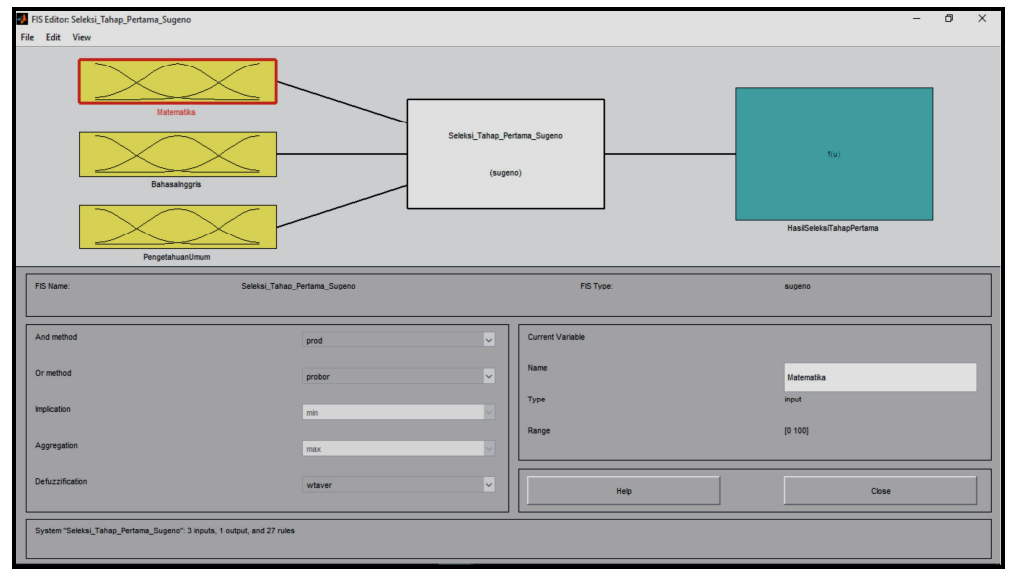

Gambar 2 Fuzzy Inference System (FIS) Metode Sugeno untuk Penentuan Variabel Input dan Variabel Output pada Seleksi Tahap Pertama

Untuk melihat atau mendapatkan hasil (output) dari penerapan logika fuzzy Sugeno pada seleksi tahap pertama ini dilakukan melalui fasilitas Rule Viewer. Sebagai contoh, untuk mahasiswa atas nama Mahasiswa 01 yang memiliki nilai hasil tes Matematika $=83$, Bahasa Inggris $=95$, dan Pengetahuan Umum $=88$, dari penerapan logika fuzzy Sugeno didapatkan hasil sebesar 87,8 sebagaimana tercantum dalam Gambar 3.

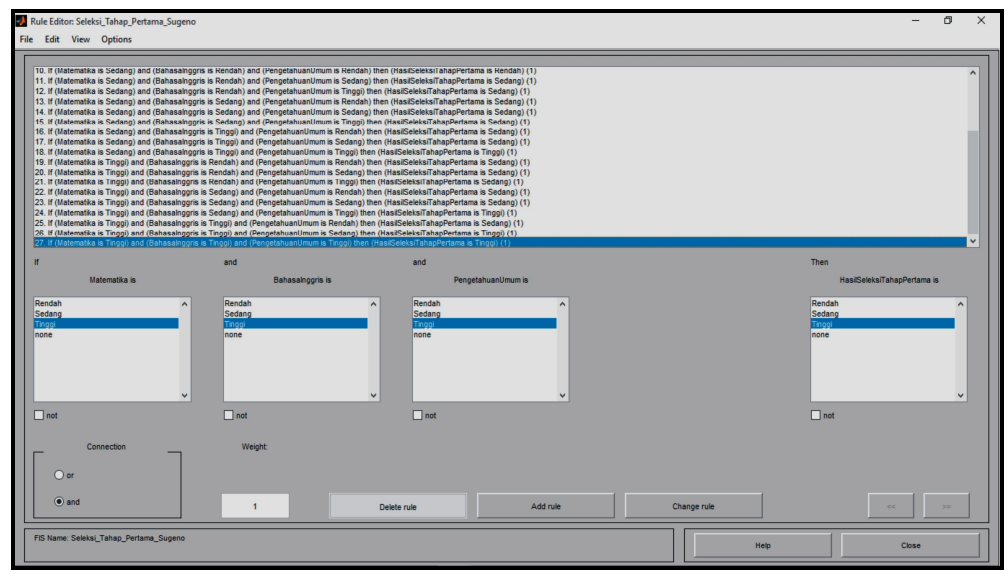

\section{Gambar 3 Rule Editor untuk Penentuan Aturan (Rule) Metode Sugeno pada Seleksi Tahap} Pertama

Adapun komposisi aturan-aturan (rules) yang digunakan dalam penerapan metode logika fuzzy Sugeno pada seleksi tahap pertama ini sama dengan komposisi aturan dalam penerapan metode logika fuzzy Mamdani yaitu terdiri dari 27 (dua puluh tujuh) aturan sebagaimana dalam uraian terdahulu.

Tabel 3 Data Hasil Tes Tahap Akhir Menggunakan Metode Logika Fuzzy Sugeno Berdasarkan Kombinasi Hasil Tiga Tahapan Seleksi : Mamdani, Mamdani, Mamdani

\begin{tabular}{|l|l|l|l|l|l|c|}
\hline \multirow{2}{*}{ NO } & \multirow{2}{*}{ NAMA } & \multicolumn{2}{|l|}{ KOMBINASI HASIL TAHAPAN SELEKSI } & \multirow{2}{*}{$\begin{array}{l}\text { HASIL AKHIR } \\
\text { (SUGENO) }\end{array}$} & \multirow{2}{*}{ IPK } \\
\cline { 3 - 5 } & & PERTAMA & KEDUA & KETIGA & \\
\cline { 3 - 5 } & & MAMDANI & MAMDANI & MAMDANI & & \\
\hline \hline & & & & & 85,3 & 4,00 \\
\hline 1 & Mahasiswa 01 & 86,7 & 85,1 & 86,7 & & \\
\hline
\end{tabular}




\begin{tabular}{|c|c|c|c|c|c|c|}
\hline \multirow{3}{*}{ NO } & \multirow{3}{*}{ NAMA } & \multicolumn{3}{|c|}{ KOMBINASI HASIL TAHAPAN SELEKSI } & \multirow{3}{*}{$\begin{array}{l}\text { HASIL AKHIR } \\
\text { (SUGENO) }\end{array}$} & \multirow{3}{*}{ IPK } \\
\hline & & \multirow{2}{*}{$\begin{array}{l}\text { PERTAMA } \\
\text { MAMDANI }\end{array}$} & \multirow{2}{*}{$\begin{array}{l}\text { KEDUA } \\
\text { MAMDANI }\end{array}$} & \multirow{2}{*}{$\begin{array}{l}\text { KETIGA } \\
\text { MAMDANI }\end{array}$} & & \\
\hline & & & & & & \\
\hline 2 & Mahasiswa 02 & 51,5 & 86,2 & 86,7 & 74,1 & 3,55 \\
\hline 3 & Mahasiswa 03 & 60,0 & 85,1 & 86,7 & 76,5 & 3,25 \\
\hline 4 & Mahasiswa 04 & 55,6 & 85,1 & 86,7 & 75,0 & 3,55 \\
\hline 5 & Mahasiswa 05 & 60,0 & 85,1 & 86,2 & 76,3 & 3,55 \\
\hline 6 & Mahasiswa 06 & 60,0 & 85,1 & 86,2 & 76,3 & 3,55 \\
\hline 7 & Mahasiswa 07 & 31,3 & 85,1 & 86,7 & 67,0 & 3,15 \\
\hline 8 & Mahasiswa 08 & 32,1 & 85,1 & 86,7 & 63,7 & 3,25 \\
\hline 9 & Mahasiswa 09 & 48,0 & 85,1 & 86,7 & 72,5 & 3,55 \\
\hline 10 & Mahasiswa 10 & 24,6 & 85,1 & 86,7 & 64,8 & 3,45 \\
\hline 11 & Mahasiswa 11 & 51,7 & 85,1 & 86,7 & 73,8 & 3,45 \\
\hline 12 & Mahasiswa 12 & 86,7 & 86,2 & 86,7 & 85,7 & 3,55 \\
\hline 13 & Mahasiswa 13 & 86,7 & 86,2 & 86,2 & 85,5 & 3,85 \\
\hline 14 & Mahasiswa 14 & 82,6 & 85,1 & 86,2 & 83,8 & 3,00 \\
\hline 15 & Mahasiswa 15 & 60,0 & 85,1 & 86,7 & 76,5 & 3,85 \\
\hline 16 & Mahasiswa 16 & 60,0 & 85,1 & 86,2 & 76,3 & 4,00 \\
\hline 17 & Mahasiswa 17 & 31,3 & 85,1 & 86,2 & 66,9 & 3,25 \\
\hline 18 & Mahasiswa 18 & 44,6 & 85,1 & 86,2 & 71,2 & 3,25 \\
\hline 19 & Mahasiswa 19 & 24,6 & 85,1 & 86,7 & 64,8 & 3,55 \\
\hline 20 & Mahasiswa 20 & 24,6 & 85,1 & 86,7 & 64,8 & 3,10 \\
\hline 21 & Mahasiswa 21 & 22,8 & 85,1 & 86,2 & 64,1 & 3,15 \\
\hline 22 & Mahasiswa 22 & 25,0 & 85,1 & 86,2 & 64,8 & 2,30 \\
\hline 23 & Mahasiswa 23 & 24,8 & 85,1 & 86,7 & 64,9 & 3,55 \\
\hline
\end{tabular}

Hasil yang diperoleh dari penerapan metode logika fuzzy Sugeno pada seleksi tahap pertama, tahap kedua, tahap ketiga, serta tahap akhir di atas djadikan sebagai bahan analisa perbandingan (komparasi) dengan hasil penerapan logika fuzzy Mamdani sebagaimana dalam uraian terdahulu.

\section{Pembahasan Hasil Penelitian}

Hasil pengolahan data yang diperoleh pada bagian hasil penelitian, digunakan untuk melakukan analisis perbandingan (komparasi) antara penerapan metode logika fuzzy Mamdani dengan penerapan metode logika fuzzy Sugeno untuk dapat ditentukan metode logika fuzzy yang lebih baik diterapkan pada setiap tahapan seleksi penerimaan mahasiswa baru program studi Diploma III Akuntansi STIE Binaniaga melalui jalur beasiswa, sebagai alternatif untuk menggantikan metode rata-rata yang selama ini digunakan.

Sebagai bahan analisis perbandingan pula, terlebih dahulu dideskripsikan visualisasi indeks prestasi kumulatif (IPK) berdasarkan data terurut hasil akhir penerapan metode rata-rata yang selama ini digunakan STIE Binaniaga. Data nilai akhir yang sudah diurutkan secara descending (terbesar ke terkecil) dan indeks prestasi kumulatif (IPK) yang bersesuaian sebagaimana tersaji dalam tabel 4

Tabel 4 Data Terurut Hasil Tes Tahap Akhir Menggunakan Metode Rata-Rata dan Indeks Prestasi Kumulatif (IPK) Mahasiswa 


\begin{tabular}{|c|c|c|c|}
\hline NO. & NAMA & $\begin{array}{l}\text { NILAI } \\
\text { AKHIR } \\
\text { (RATA-RATA }\end{array}$ & $\begin{array}{l}\text { INDEKS } \\
\text { PRESTASI } \\
\text { KUMULATIF }\end{array}$ \\
\hline 1 & Mahasiswa 01 & 90 & 4,00 \\
\hline 2 & Mahasiswa 12 & 90 & 3,55 \\
\hline 3 & Mahasiswa 13 & 85 & 3,85 \\
\hline 4 & Mahasiswa 14 & 80 & 3,00 \\
\hline 5 & Mahasiswa 14 & 79 & 3,85 \\
\hline 6 & Mahasiswa 02 & 78 & 3,55 \\
\hline 7 & Mahasiswa 16 & 77 & 4,00 \\
\hline 8 & Mahasiswa 03 & 76 & 3,25 \\
\hline 9 & Mahasiswa 08 & 75 & 3,25 \\
\hline 10 & Mahasiswa 04 & 74 & 3,55 \\
\hline 11 & Mahasiswa 10 & 74 & 3,45 \\
\hline 12 & Mahasiswa 09 & 73 & 3,55 \\
\hline 13 & Mahasiswa 19 & 73 & 3,55 \\
\hline 14 & Mahasiswa 11 & 73 & 3,45 \\
\hline 15 & Mahasiswa 07 & 73 & 3,15 \\
\hline 16 & Mahasiswa 05 & 72 & 3,55 \\
\hline 17 & Mahasiswa 06 & 72 & 3,55 \\
\hline 18 & Mahasiswa 17 & 72 & 3,25 \\
\hline 19 & Mahasiswa 20 & 72 & 3,10 \\
\hline 20 & Mahasiswa 18 & 71 & 3,25 \\
\hline 21 & Mahasiswa 21 & 69 & 3,15 \\
\hline 22 & Mahasiswa 23 & 66 & 3,55 \\
\hline 23 & Mahasiswa 22 & 65 & 2,30 \\
\hline
\end{tabular}

Adapun visualisasi indeks prestasikumulatif (IPK) berdasarkan nilai terurut hasil akhir dari penggunaan metode rata-rata sebagaimana tersaji dalam Gambar 22.

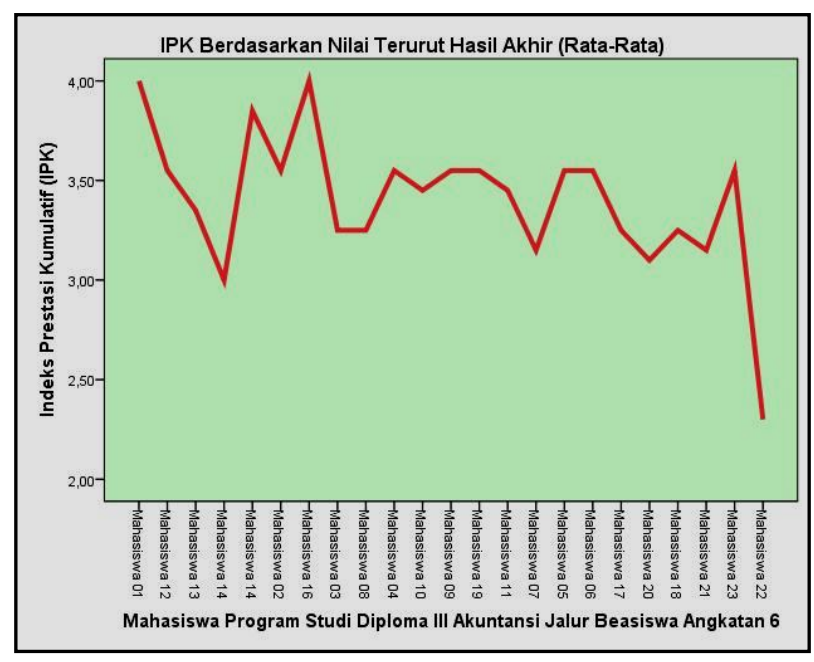

Gambar 4 Pola Indeks Prestasi Kumulatif (IPK) Berdasarkan Nilai Terurut Hasil Akhir (RataRata) 
Tampilan Gambar 22 tersebut akan didampingkan dengan visualisasi indeks prestasi kumulatif (IPK) berdasarkan nilai terurut hasil akhir dari penerapan masing-masing kombinasi metode logika fuzzy pada uraian berikutnya. Hal tersebut dimaksudkan untuk mendapatkan deskripsi kelebihbaikan atau kekurangbaikan pola visualisasi indeks prestasi kumulatif (IPK) dari penerapan masing-masing kombinasi metode logika fuzzy sebagai alternatif untuk menggantikan metode rata-rata yang selama ini digunakan.

Adapun nilai koefisien korelasi linear antara indeks prestasi kumulatif (IPK) dengan hasil akhir dari penerapan metode rata-rata adalah sebesar 0,559 sebagaimana tersaji dalam Gambar 23.

Nilai koefisien korelasi linear sebesar 0,559 termasuk dalam kategori positif, dalam arti semakin tinggi hasil akhir dari penerapan metode rata-rata maka akan semakin tinggi juga indeks prestasi kumulatif (IPK). Atau sebaliknya, semakin rendah hasil akhir dari penerapan metode rata-rata maka akan semakin rendah pula indeks prestasi kumulatif (IPK).

\begin{tabular}{||ll|r|r||}
\hline \multicolumn{4}{|c|}{ Correlations } \\
\hline & & $\begin{array}{r}\text { Hasil_Akhir_ } \\
\text { RATA_RATA }\end{array}$ & $\begin{array}{r}\text { IPK_RATA_R } \\
\text { ATA }\end{array}$ \\
\hline Hasil_Akhir_RATA_RATA & Pearson Correlation & 1 & $.559^{\prime \prime}$ \\
& Sig. (2-tailed) & & .006 \\
& $\mathrm{~N}$ & 23 & 23 \\
\hline IPK_RATA_RATA & Pearson Correlation & $.559^{\prime \prime}$ & 1 \\
& Sig. (2-tailed) & .006 & \\
& $\mathrm{~N}$ & 23 & 23 \\
\hline \multirow{2}{*}{ *. Correlation is significant at the 0.01 level (2-tailed). } \\
\hline
\end{tabular}

Gambar 5 Koefisien Korelasi Linear antara Indeks Prestasi Kumulatif (IPK) dengan Hasil Akhir (Rata-Rata)

Nilai koefisien korelasi linear pada Gambar 23 juga dimaksudkan untuk mendapatkan deskripsi kelebihbaikan atau kekurangbaikan penerapan masing-masing kombinasi metode logika fuzzy sebagai alternatif untuk menggantikan metode rata-rata yang selama ini digunakan.

Selanjutnya, analisis perbandingan (komparasi) diawali dengan deskripsi kesesuaian visualisasi pola prestasi akademik berdasarkan data terurut setelah penerapan metode logika fuzzy Mamdani ataupun metode logika fuzzy Sugeno pada seleksi tahap akhir dari masingmasing data hasil kombinasi penerapan metode logika fuzzy pada seleksi tahap pertama, seleksi tahap kedua, dan seleksi tahap ketiga terhadap visualisasi pola prestasi akademik sebagai harapan minimal yang diinginkan STIE Binaniaga sebagaimana tertuang dalam Gambar 1.2 pada uraian BAB I terdahulu. Analisis perbandingan (komparasi) diutamakan menggunakan alat analisa berupa hubungan (korelasi) antara indeks prestasi kumulatif (IPK) dengan hasil penerapan metode logika fuzzy pada seleksi tahap akhir yang data inputannya berasal dari hasil masing-masing kombinasi penerapan metode logika fuzzy pada seleksi tahap pertama, seleksi tahap kedua, dan seleksi tahap ketiga. Nilai koefisien korelasi terbesar dan lebih tinggi dari 0,559 (metode rata-rata) yang didapatkan, maka metode logika fuzzy tersebut yang lebih baik diterapkan pada seleksi tahap akhir termasuk kombinasi penerapan metode logika fuzzy yang diterapkan pada seleksi tahap pertama, seleksi tahap kedua, dan seleksi tahap ketiga dinyatakan lebih baik diterapkan pada tahapan seleksi bersesuaian. 
Analisa perbandingan metode logika fuzzy sebagai pendukung keputusan pada setiap tahapan seleksi penerimaan mahasiswa baru program studi Diploma III Akuntansi STIE Binaniaga melalui jalur beasiswa adalah sebagaimana dalam uraian berikutnya.

\section{Kesimpulan dan Saran}

\section{Kesimpulan}

Berdasarkan uraian hasil dan pembahasan perbandingan (komparasi) penerapan metode logika fuzzy Mamdani dan metode logika fuzzy Sugeno sebagai pendukung keputusan seleksi bertahap, mengingat nilai koefisien korelasi linier antara indeks prestasi kumulatif (IPK) dengan hasil seleksi bertahap dari penerapan kombinasi metode logika fuzzy tertinggi dan lebih besar dari 0,559 (metode rata-rata) dicapai pada penerapan kombinasi logika fuzzy SMSS (Sugeno, Mamdani, Sugeno, Sugeno) yaitu sebesar 0,579 maka kesimpulan sebagai jawaban dari rumusan masalah dalam penelitian ini adalah sebagai berikut:

1. Metode logika fuzzy Sugeno lebih baik untuk diterapkan pada seleksi tahap pertama (tes tertulis) penerimaan mahasiswa baru program studi Diploma III Akuntansi STIE Binaniaga melalui jalur beasiswa.

2. Metode logika fuzzy Mamdani lebih baik untuk diterapkan pada seleksi tahap kedua (psychotest) penerimaan mahasiswa baru program studi Diploma III Akuntansi STIE Binaniaga melalui jalur beasiswa

3. Metode logika fuzzy Sugeno lebih baik untuk diterapkan pada seleksi tahap ketiga (wawancara) penerimaan mahasiswa baru program studi Diploma III Akuntansi STIE Binaniaga melalui jalur beasiswa.

4. Metode logika fuzzy Sugeno lebih baikuntuk diterapkan pada seleksi tahap akhir (penentuan besaran beasiswa) penerimaan mahasiswa baru program studi Diploma III Akuntansi STIE Binaniaga melalui jalur beasiswa.

\section{Saran}

Sehubungan dengan masih terdapatnya keterbatasan dari penelitian yang penulis lakukan yaitu dalam hal data perkembangan akademik berupa indeks prestasi kumulatif (IPK) hanya berasal dari hasil studi mahasiswa selama satu semester, maka penulis menyarankan untuk melakukan penelitian lanjutan dan sejenis sesuai perkembangan prestasi akademik mahasiswa pada masa yang akan datang.

\section{Daftar Pustaka}

Abidah, Siti, Analisis Komparasi Metode Tsukamoto dan Sugeno dalam Prediksi Jumlah

Siswa Baru, Journal Speed, Volume 8 Nomor 2, 2016.

Aprizal, Muhammad, Dedi Rahman, Mardiani, Perbandingan Metode Logika Fuzzy

Tsukamoto dan Logika Fuzzy Mamdani dalam Pemilihan Penerima Beasiswa pada STMIK Global Informatika MDP, STMIK GI MDP. 
Djunaidi, Much., Eko Setiawan, Fajar Whedi Andista, Penentuan Jumlah Produksi dengan Aplikasi Metode Fuzzy Mamdani, Jurnal IImiah Teknik Industri, Vol. 4 No. 2, 2005.

Istraniady, Priko Andrian, Mardiani, Analisis Perbandingan Metode Fuzzy Tsukamoto dan Metode Fuzzy Mamdani pada Perbandingan Harga Sepeda Motor Bekas, STMIK GI MDP.

Kusumadewi, Sri, Hari Purnomo, Aplikasi Logika Fuzzy untuk Pendukung Keputusan, Edisi II. Yogyakarta: Graha IImu, 2010.

STIE Binaniaga, Pedoman Penerimaan Mahasiswa Baru STIE Binaniaga, STIE Binaniaga. 2016.

STIE Binaniaga, Program Peningkatan Penerimaan Mahasiswa Baru Melalui "Institute Social Responsibility Project ( ISRP )" Beasiswa Pendidikan 100\%, STIE Binaniaga, 2016.

STIE Binaniaga, Rencana Strategi STIE Binaniaga 2015-2020, STIE Binaniaga. 2015.

STIE Binaniaga, Statuta STIE Binaniaga, STIE Binaniaga. 2010.

Subekti, Sri Ayu, Penggunaan Metode Fuzzy Mamdani dan Sugeno untuk Pengambilan Keputusan dalam Analisis Kredit, Studi Kasus: Pengambilan Keputusan Kredit PT. Kandimadu Arta Cabang Salatiga, Universitas Kristen Satya Wacana, Salatiga, 2014.

Triyanto, Agus, Febri Baruna Kesuma, Shinta Puspasari, Studi Perbandingan Metode Fuzzy Tsukamoto dan Fuzzy Mamdani untuk Seleksi Pegawai Teladan pada PT. Gracia Pharmindo. STMIK GI MDP.

Walpole, Ronald E., Pengantar Statistika (Edisi Ke-3), PT. Gramedia, Jakarta, 1988.

Yudihartanti, Yulia, Abdul Syukur, Romi Satria Wahono, Analisis Komparasi Metode Mamdani dan Sugeno dalam Penjadwalan Mata Kuliah, Jurnal Teknologi Informasi, Volume 7 Nomor 2, 2011. 